\title{
MODAL DASAR MENJADI KEPALA SEKOLAH
}

\section{Riduan Saberan $^{1}$ \& Erni Susilawati ${ }^{2}$}

\section{Pendidikan Bahasa \& Sastra Indonesia STKIP PGRI Banjarmasin riduansaberan@stkipbjm.ac.id (0811504113) \\ 2. Pendidikan Bahasa \& Sastra Indonesia STKIP PGRI Banjarmasin ernisusilawati@stkipbjm.ac.id (085248362821)}

\begin{abstract}
ABSTRAK
Pendidikan merupakan persoalan setrategis bagi suatu bangsa. Pendidikan yang berkualitas bukan hanya penting bagi upaya melahirkan individu dan masyarakat terpelajar, akan tetapi juga menjadi bekal utama sebagai persiapan memasuki kompetisi global. Agar bisa memenangkan persaingan global dalam pendidikan, maka pendidikan di Indonesia harus diberdayakan secara optimal dan secepat mungkin serta terus dikembangkan semangat kemitraan dengan stakeholders. Tujuan pendidikan akan tercapai bila kondisi sekolah yang kondusif sehingga aktifitas belajar mengajar bisa berjalan dengan lancar maka yang terpenting adalah kemampuan kepala sekolah sangat diperlukan dalam mengelola dan menciptakan iklim sekolah yang kondusif. Untuk menentukan kualitas pendidikan antara lain diperlukan majemen sekolah yang berkualitas. Kepala sekolah sebagai pemegang manajemen sekolah, maka ia harus memiliki kemampuan dasar seperti manajerial, yakni sosok kepala sekolah yang memperhatikan manajemen sumber daya manusia lambat laun akan menciptakan dirinya berdaya dalam mengelola sebuah sekolah menuju harapan sebuah pihak, integritas kepala sekolah yang tinggi, serta kemampuan dalam menciptakan iklim organisasi.
\end{abstract}

Kata kunci : modal dasar, kepala sekolah

\section{PENDAHULUAN}

Kepala sekolah harus memiliki keterampilan-keterampilan profesional yang efektif dalam fungsi-fungsi administrasi pendidikan. Mengemukakan bahwa keterampilan adalah kompetensi yang berhubungan dengan pekerjaan (Gibson, Invancevich, dan Donnely, 1996; Nadler, 1982). Dari pendapat ini, keterampilan dapat diartikan sebagai kemampuan dalam melaksanakan tugas berdasarkan kompetensi yang berkaitan dengan pekerjaan dan dapat diamati.

Untuk menjadi kepala sekolah yang diidamkan tersebut, banyak ihwal terkait kemampuan dan keahlian yang harus dimiliki oleh seorang kepala sekolah. Baik buruknya kinerja sebuah sekolah harus dilihat bagaimana seorang kepala sekolah memimpin dan mengelola sebuah sekolah. Sekolah akan hancur dan tidak mencapai tujuan jika salah satunya tidak memiliki pemimpin, yakni memiliki pemimpin yang handal. Kemampuan managerial dan keahlian pengelola organisasi sekolah harus dipertaruhkan oleh siapapun yang berminat menjadi kepala sekolah.

Baru-baru ini, muncul berita di televisi, bahwa ada sebiah sekolah yang harus dipindahkan lokasinya ke tempat yang jauh dari keramaian. Entah akibat dari konspirasi penjabat daerah dengan pimpinan lembaga sebuah sekolah negeri, 
banyak protes yang mengarah pada kekerasan yang berujung pada tindakan anarkis. Akibatnya anak didik dan siswa menjadi korbannya. Kasus serupa mungkin juga terjadi di beberapa tempat di Indonesia, dan salah satu pihak yang harus disalahkan adalah pimpinan lembaga pendidikan yakni kepala sekolah.

Berangkat dari latar belakang runyamnya dunia pendidikan di Indonesia yang dikategorikan sebagai lemahnya kemampuan manajerial yang harus dimiliki oleh seorang kepala sekolah, maka rumusan masalah tulisan ini terletak pada bagaimana seharusnya seorang kepala sekolah mengelaborasi kemampuan manajerial dalam perspektif sumber daya manusia demi menciptakan suasana yang kondusif bagi dunia pendidikan?

\section{A. Tugas Kepala Sekolah}

\section{PEMBAHASAN}

Kepala sekolah adalah seorang pemimpin yang menjalankan proses pendidikan dan pengajaran di suatu sekolah. Kepala sekolah bukan hanya sekedar kedudukan ataupun jabatan, tetapi merupakan suatau pekerjaan yang penuh dengan tanggung jawab, komitmen, jujur, adil, dan memiliki visi yang teguh, serta konsekwen dengan hal-hal yang telah ditetapkan untuk menyelenggarakan proses pembelajaran.

Kepala sekolah dituntut mampu menterjemahkan kepada guru, karyawan dan pihak-pihak yang terlibat dalam proses pembelajaran tentang visi, misi, nilainilai, strategi transformasi serta keterampilan dalam menghadapi dinamika yang timbul, tumbuh, dan berkembang di sekolah yang dipimpinnya. Selain itu seorang kepala sekolah harus mampu memberikan motivasi, inspirasi dan pemberdayaan para guru, siswa, dan semua karyawannya.

Kepala sekolah harus memiliki integritas yang tinggi sehingga kekuatan kepemimpinannya membawa pengaruh ke arah positiv bagi pertumbuhan dan pengajaran di sekolah. Menurut Harefa (2000:147) integritas adalah, maitaining social, ethical, and organizational norm, firmly adhering to code of conduct and ethical prinsiple. Dengan pengertian tersebut integritas diterjemahkan menjadi tiga tindakan kunci yang dapat diamati. Pertama, menunjukan kejujuran, yaitu bekerja dengan orang lain secara jujur dan benar, menyajikan data dan informasi secara benar dan akurat. Kedua, memenuhi komitmen, yaitu melakukan apa yang telah dijanjikan dan tidak membocorkan rahasia. Ketiga, berprilaku secara konsisten, yaitu menunjukan tidak adanya kesenjangan antara kata dan perbuatan. Untuk menjadi kepala sekolah yang baik, maka seorang kepala sekolah harus memiliki kemampuan dasar, sehingga majemen pendidikan bisa diterapkan untuk mencapai tujuan pendidikan yang diinginkan bersama.

\section{B. Kemampuan Dasar yang Harus Dimiliki Oleh Kepala Sekolah 1. Kemampuan Manajerial}

Manajer adalah orang-orang yang menjalankan fungsi-fungsi manajemen, dan menggunakan semua sumber daya organisasi (orang, keuangan, peralatan dan informasi) untuk mencapai tujuannya (Terry, 1987; Stoner, 1989). Keterampilan manajerial dapat diartikan sebagai kemampuan melaksanakan tugas berdasarkan kompetensi, yang dilakukan seorang dalam mencapai tujuan, bekerjasama dengan orang lain. 
Menurut tingkatannya, pimpinan dalam organisasi dapat dikelompokkan menjadi 3 tingkatan, yaitu: (1) manajemen puncak (top management), (2) manajemen menengah (middle management), dan manajemen rendah (lower management) (Burhanuddin, 1994). Dapat dikatakan bahwa, administrative management berada pada tingkat top management, sedangkan middle management pada tingkat pimpinan menengah, dan supervisory management pada tingkat paling bawah.

Pada tingkatan administrative management, lebih banyak menggunakan kerja fikir daripada kerja fisik dalam memimpin organisasi, misalnya menentukan tujuan organisasi, perumusan kebijakan, penggerakkan kelompok pimpinan pada tingkat yang lebih rendah dan memikirkan pada hal-hal yang sifatnya lebih menyeluruh. Untuk itu "managerial skill" lebih dibutuhkan. Sedangkan pada tingkat middle management, dalam tugas kegiatannya sehari-hari antara kegiatan fikir dan fisik hampir seimbang, kedua-duanya dilaksanakan hampir serempak dan bersama-sama. Sebaliknya, pada tingkat supervosiry management, dalam tugas sehari-hari pimpinan lebih banyak menggunakan kerja fisik daripada kerja fikir. Untuk itu, dia lebih banyak membutuhkan "technical skill" daripada managerial skills.

Terdapat tiga kelompok keterampilan manajerial kepala sekolah yaitu conceptual skills, human relation skill, dan technical skill. conceptual skills adalah kemampuan yang berhubungan keterampilan dari segi ide (fikiran), relation skill adalah kemampuan yang berhubungan keterampilan berhubungan dengan orang lain, sedangkan technical skill adalah kemampuan yang berhubungan dengan keterampilan-keterampilan teknis dalam menangani sesuatu yang terkait organisasi (Elsbree, 1967). Keterampilan konseptual meliputi perencanaan, pengorganisasian, pelaksanaan dan pengawasan. Keterampilan hubungan manusia meliputi kerjasama, motivasi, komunikasi, sikap, moral, kesejahteraan dan mengelola konflik. Adapun keterampilan teknikal mencakup keterampilan teknik dan proses belajar mengajar, dalam membimbing siswa, serta dalam pertanggungjawabannya.

Keterampilan manajerial kepala sekolah merupakan bagian dari kinerja kepala sekolah (Dirjen Dikdasmen Depdiknas, 2000). Ada 7 komponen penilaian seorang kepala sekolah, yaitu:

1. Komponen kepala sekolah sebagai pendidik (educator), meliputi aspekaspek: (a) aspek prestasi sebagai guru, (b) aspek kemampuan membimbing guru, (c) aspek kemampuan membimbing karyawan (d) aspek kemampuan membimbing siswa, (e) aspek kemampuan mengembanghkan staf, (f) aspek kemampuan belajar dan mengikuti perkembangan iptek, dan (g) aspek kemampuan memberi contoh mengajar yang baik.

2. Komponen kepala sekolah sebagai manajer (manager), meliputi aspek-aspek: (a) aspek kemampuan menyusun program, (b) aspek kemampuan menyusun organisasi/kepegawaian di sekolah, (c) aspek kemampaun menggerakkan staf, dan (d) aspek kemampuan mengoptimalkan sumber daya sekolah.

3. Komponen kepala sekolah sebagai administrator (administrator), meliputi aspek-aspek: (a) aspek kemampuan mengelola organisasi KBM dan BK, (b) aspek kemampaun mengelola administrasi kesiswaan, (c) aspek kemampaun mengelola administrasi ketenagaan, (d) aspek kemampaun mengelola administrasi keuangan, (e) aspek kemampaun mengelola administrasi 
sarana/prasarana, dan (f) aspek kemampaun mengelola administrasi persuratan.

4. Komponen kepala sekolah sebagai penyelia (supervisor), melipti aspekaspek: (a) aspek kemampuan menyusun program supervisi, (b) aspek kemampuan melaksanakan supervisi pendidikan, dan (c) aspek kemampuan memanfaatkan supervisi.

5. Komponen kepala sekolah sebagai pemimpin (leader), meliputi aspek-aspek: (a) aspek kepribadian yang kuat, (b) aspek kemampuan mengenal anak buah,

(c) aspek pemahaman terhadap visi dan misi sekolah, (d) aspek kemampuan mengambil keputusan, dan (e) aspek kemampuan komunikasi.

6. Komponen kepala sekolah sebagai Innovator (innovator), meliputi aspekaspek: (a) aspek kemampaun mencari atau menemukan gagasan baru, (b) aspek kemampuan melakukan pembaharuan di sekolah.

7. Komponen kepala sekolah sebagai motivator (motivator), meliputi aspekaspek: (a) aspek kemampuan mengatur lingkungan kerja (fisik), (b) aspek kemampuan mengatur suasana kerja (nonfisik), dan (c) aspek kemampuan menerapkan prinsp penghargaan dan hukuman.

Secara hierarkis, keterampilan manajerial kepala sekolah dapat dipaparkan sebagai berikut (Dirjen Dikdasmen Depdiknas, 2000).

a. Ada 4 indikator aspek kemampuan menyusun program, yaitu:

1. Memiliki program jangka panjang ( 8 tahun): akademik dan nonakademik

2. Memiliki program jangka menengah (4 tahun) : akademik dan nonakademik

3. Memiliki program jangka pendek (1 tahun) : akademik dan nonakademik dan RAPBS

4. Mempunyai mekanisme monitor dan evaluasi pelaksanaan program secara sistematika dan periodik

b. Ada 3 indikator aspek kemampuan menyusun organisasi kepegawaian di sekolah, yaitu:

1. Memiliki susunan kepegawaian di sekolah

2. Memiliki susunan kepegawaian pendukung antara lain pengelola perpustakaan

3. Penyusun kepanitiaan untuk kegiatan temporer, antara lain panitia ulangan umum, panitia ujian, panitia peringatan hari besar keagamaan, dan lain sebagainya

c. Ada 3 indikator aspek kemampuan menggerakkan staf (guru dan karyawan), yaitu:

1. Memberikan arahan yang dinamis

2. Mengkoordinasikan staf yang sedang melaksanakan tugas

3. Memberikan pengjargaan (reward) dan hukuman (punishment)

d. Ada 5 indikator aspek kemampuan mengoptimalkan sumber daya sekolah, yaitu:

1. Memanfaatkan sumber daya manusia secara optimal

2. Memanfaatkan sarana dan prasarana secara optimal

3. Merawat sarana dan prasarana milik sekolah

4. Mempunyai catatan kinerja sumber daya manusia yang ada di sekolah

5. Mempunyai program peningkatan mutu sumber daya manusia 


\section{Iklim Organisasi}

Di samping kemampuan manajerial, memperhatikan organisasi sebagai sebuah sistem patut dikedepankan. Organisasi pada dasarnya merupakan sekumpulan sekelompok orang. Adanya keterbatasan pada manusia mendorong untuk membentuk organisasi. Organisasi merupakan suatu sistem yang terdiri dari sub subsistem atau bagian-bagian saling berkaitan satu sama lainnya dalam melakukan aktivitasnya (Gitusudarmo, dkk, 2000). Organisasi sebagai suatu sistem adalah sistem terbuka, dimana batas organisasi sangatlah lentur dan menganggap bahwa faktor lingkungan sebagai infut. Organisasi selalu peka dan berupaya untuk selalu beradaptasi dengan perubahan-perubahan yang terjadi pada faktor lingkungan eksternal. Yang termasuk faktor eksternal yang dimaksud adalah selera konsumen, teknologi, sosiopolitik, penduduk, sosial budaya dan lainnya.

Beberapa unsur yang harus diperhatikandalam suatu organisasi adalah: (1) adanya sekelompok orang (man), (2) adanya pola aktivitas orang-orang yang ada dalam organisasi (activity), (3) adanya tujuan organisasi (goals). Ketiganya adalah merupakan syarat mutlak keberadaan suatu organisasi. Tiga komponen tersebut dapat dioptimalkan secara sinergis untuk membentuk suatu organisasi yang kuat.

Iklim organisasi adaalah lingkungan manusia dimana para pegawai organisasi melakukan pekerjaan mereka (Davis, et al 1985). Pengertian ini dapat mengacu pada suatu lingkungan departemen, unit perusahaan, atau suatu organisais secara keseluruhan. Iklim tidak dapat dilihat atau disentuh, tetapi ia ada. Iklim organisasi selalu unik. Masing-masing organisasi memiliki budaya, tradisi, dan metode tindakannya sendiri yang secara keseluruhan menciptakan iklimnya. Sebagian organisasi sibuk dan efisien, yang lain tampak santai. Sebagian cukup manusiawi, yang lain keras dan dingin. Organisasi cenderung menarik dan mempertahankan orang-orang yang sesuai dengan iklimnya, sehingga pada tingkat tertentu, polanya dapat langgeng. Sama halnya dengan orang-orang yang memilih untuk pindah ke iklim geografis tertentu seperti pantai, pegunungan atau padang pasir, mereka dapat juga memilih iklim organisasi yang disukai.

Iklim organisasi adalah persepsi individu yang memiliki bermacammacam aspek lingkungan di dalam sebauh organisasi (Owens, 1991; Hoy dan Miskel, 1987; De Roche, 1985). Sergiovanni, (1987) mengutip pendapat Pitchard dan Karasick (1973) mengartikan iklim organisasi sebagai suatu karakteristik sekolah yang membedakannya dengan sekolah yang lain, mempengaruhi perilaku kepala sekolah, guru, dan siswa dan dipengaruhi oleh model perilaku anggota organisasi. Dari penegrtian ini dapat disarikan bahwa aspek definisi iklim organisasi sebagai berikut: (a) iklim organisasi berkaitan dengan unit yang besar yang mengandung ciri karakteristik tertentu, (2) iklim organisasi berasal dari praktik organisasi, dan (3) iklim organisasi mempengaruhi dan dipengaruhi oleh perilaku dan sikap anggota.

Hoy dan Miskel (1987) telah mengidentifikasi kontinum iklim organisasi berdasarkan hasil penelitian Halpin (1971) yang menggunakan organisasi “Organizational Climate Description Questionaire) (OCDQ). Pada intinya, terdapat enam klasifikasi iklim organisasi, yaitu sebagai berikut:

1. "Open Climate" yang menggambarkan situasi dimana para anggota senang sekali bekerja, saling bekerjasama, dan adanya keterbukaan. Iklim organisasi 
terbuka juga melukiskan organisasi penuh semangat dan daya hidup, memberikan kepuaskan pada anggota kelompok dalam memenuhi kebutuhankebutuhannya. Tindakan-tindakan pimpinan lancar dan serasi. Anggota kelompok mudah memperoleh kepuasan kerja karena dapat menyelesaikan tugsa-tugas dengan baik, sementara kebutuhan-kebutuhan pribadi terpenuhi. Ciri utama iklim organisasi demikian adalah adanya "kewajaran" tingkah laku semua anggota.

2. "Autonomous Climate", yaitu: situasi dimana ada kebebasan, adanya peluang kreatif, sehingga para anggota memiliki peluang untuk memuaskan kebutuhankebutuhan mereka. Iklim organisasi melukiskan suasana oranisasi, dimana tindakan kepemimpinan justru muncul pertama-tama dari kelompok. Pemimpin sedikit melakukan pengawasan, semangat kerja pertama muncul karena hanya untuk memenuhi kepuasan pribadi. Sedangkan kepuasan kerja juga muncul, hanya saja kadarnya kecil sekali. Kepuasan kerja yang dimaksud adalah kepuasan yang ditimbulkanoleh karena kegiatan tertentu dapat diselesaikan.

3. "The Controlled Climate" yang ditandai penekanan atas prestasi dalam mewujudkan kepuasan kebutuhan sosial, setiap orang bekerja keras, kurang hubungan sesama. Ikli organisasi ini bercirikan "impersonal" dan sangat mementingkan tugas. Sementara kebutuhan anggota organisasi tidak diperhatkan, anggota kelompok sendiri pada akhirnya hanya memperhatikan tugas-tugas yang ditetapkan pimpinan (karena takut dan terpaksa) yang mengakibatkan perhatian pada kebutuhannya relatif kecil. Semangat kerja kelompok tinggi, namun mencerminkan adanya pengorbanan aspek kebutuhan manusiawi. Ciri khas iklim demikian adalah ketidakwajaran tingkah laku karena kelompok hanya mementingkan tugas-tugas.

4. "The Familiar Climate", yaitu adanya rasa kesejawatan tinggi antara pimpinan dan anggota. Iklim organisasi kekeluargaan ini adalah suatu iklim yangb terlalu bersifat manusiawi, dan tidak terkontrol. Para anggota hanya berlomba-lomba untuk memenuhi tuntutan pribadi mereka, namun sangat sedikit perhatian pada penyelesaian tugas dan kontrl sosial yang ada kurang diperhatikan. Sejalan dengan itu, semangat kerja kelompok sebenarnya tidak begitu tinggi, karena kelompok mendapat kepuasan yang sedikit dalam menyelesaikan tugas-tugas. Tingkah laku demikian pun sebenarnya tidak wajar.

5. "The Paternal Climate", yang bercirikan adnaya pengontrolan pimpinan pada anggota. Kepala sekolah biasanya menekan atau tidak menghargai adanya inisiatif yang muncul dari orang-orang yang dipimpinnya. Kecakapankecakapan yang dimiliki oleh kelompok tidak dimanfaatkan untuk melengkapi kemampuan kerja kepala sekolah. Sejalan dengan itu banyak tindakan-tindakan kepemimpinan yang tidak dijalankan. Dalam iklim yang demikian sedikit kepuasan yang dirasakan bawahan, baik yang bertalian dengan hasil kerja mapun kebutuhan pribadi. Sehingga semangat kerja organisasi juga rendah.

6. "The Close Climate", yang ditandai oleh suatu situasi dimana rendahnya kepuasan dan pretasi tugas serta kebutuhan sosial para anggota, pimpinan sangat terutup terhadap para anggotanya. Para anggota biasanya bersikap acuh tak acuh atau masa bodoh. Organisasi tidak maju, semangat kerja kelompok rendah, karena para anggota disamping tidak memenuhi tuntutan pribadi, juga tidak memperoleh kepuasan hasil kerja. Tingkah laku anggota juga tidak wajar. 
Berdasarkan klasifikasi ikli organisasi tersebut, pada akhirnya Halpin sebagaimana dirujuk Hoy dan Miskel (1987) mengklasifikasikan iklim organisasi menjadi dua, yaitu "Open Climate" dan "Close Climate" yang merupakan kontinum dari yang terbuka sampai pada yang tertutup. Ada delapan komponen iklim yang dikemukakan oleh Halpin yang merupakan pemilihan dari karakteristik kelompok dan perilaku pemimpin. Kedelapan komponen itu adalah: Karakteristik Kelompok: (a) Disangagement" atau ketidakikutsertaan, yaitu suatu kadar terhadap staf cenderung tidak terlibat dan tidak "commited" terhadap pencapaian tujuan organisasi, (b) "Hindrance" atau halangan yang mengacu pada perasaan para staf bahwa piminan membebani mereka dengan tugas yang memberatkan pekerjaan mereka, (c) "Esprit" atau semangat, yaitu mengacu pada semangat kerja karena terpenuhinya kebutuhan sosial dan rasa punya prstasi dalam pekerjaan, (d) "Intimacy" atau keintiman, yaitu kadar kekohesifan antar staf dalam organisasi; dan yang termasuk perilaku pimpinan adalah (e) "Aloofness"atau keberjarakan, yaitu menggambarkan kadar perilaku pemimpin yang formal dan impersonal yang menunjukkan jarak sosial dengan staf, (f) "Produktion Emphasis" atau penekanan pada hasil yaitu mengacu pada perilaku pemimpinagar staf bekerja keras, misalnya dengan pengawasan ketat, direktif, dan menuntut hasil maksimal, (g) "Thrust" atau rasa yakin yaitu mengacu pada kadar perilaku pemimpin yang ditandai oleh kerja kerasnya agar dicontoh oleh staf, (h) "Consideration" atau perhatian, yaitu mengacu pada kadar perilaku pemimpin dengan memperlakukan staf secara manusiawi seseuai dengan martabatnya (Hoy \& Miskel, 1987; Owens, 1991).

Dari uraian di atas, ikli organisasi dapat dilihat dari dua sisi pandang, yaitu: (a) iklim organisasi dilihat dari karakteristik kelompok (anggota) terhadap organisasinya, dan (b) iklim organisasi dilihat dari hubungan antara kegiatankegiatan organisasi dan perilaku pemimpinnya. Dari sisi pandang inilah, untuk kepentingan penelitian kali ini iklim organisasi dilihat.

\section{Pelatihan}

Aspek terpenting berikutnya setelah kemampuan manajerial dan pemahaman terhadap iklim organisasi adalah aspek pelatihan. Pelatihan adalah sebuah prosedur yang diorganisasi, di mana orang secara individu atau kelompok, belajar tentang pengetahuan dan keterampilan untuk tujuan tertentu (Buford and Badeian 1987; Beach, 1990; Notoatmodjo, 1998). Halhal atau kegiatan lain yang sepadan dengan kegiatan pelatihan tersebut adalah: seminar, lokakarya, workshop, konferensi, up grading (penataran).

Batasan pelatihan menurut Mitchael (1982) adalah suatu upaya organisasi untuk mengubah sikap dan perilaku dari anggota-anggotanya melalui proses belajar dengan tujuan untuk meningkatkan efektifitas. Pada dasarnya bahwa pelatihan adalah pembelajaran.

Seminar, berasal dari bahasa Latin yang artinya bibit atau bisa juga disebut menabur. Sahertian (1976) memberikan pengertian seminar dalam 2 arti, yaitu: (1) sebagai tempat belajar yang juga disebut seminar yang kemudian diamakan dengan Perguruan Tinggi atau Universitas, dan (2) suatu bentuk belajar mengajar berkelompok dimana sejumlah kecil (antara 10-15 orang) mengadalam pendalaman atau penyelidikan tersendiri bersama-sama terhadap pelbagai 
masalah dengan dibimbing secara cermat oleh seorang atau lebih pengajar pada waktu tertentu, kelompok ini bertemu untuk mendengarkan laporan salah seorang anggotanya maupun untuk mendiskusinya masalah-masalah yang dikumpulkan oleh anggota kelompok. Perkembangan seminar sekarnag, diartikan tidak saja interaksi belajar mengajar, tetapi diartikan sebagai pembahasan-pembahasan mengenai suatu masalah yang bersifat ilmiah dengan pokok pembahasannya disampaikan oleh beberapa orang ahli (Thoha, 1977). Sedangkan lokakarya atau workshop lebih bersifat applicable dapat diterapkan) yang hasilnya akan bermanfaa langsung untuk diterapkan pada kegiatan kerja sehari-hari. Begitu pula dengan penataran dan koferensi.

Ada beberapa alasan yang mendasari perlunya pelatihan bagi kepala sekolah, antara lain bahwa dunia pendidikan semakin berkembanng, sehingga pendidikan pra-jabatan yang pernah diikuti oleh kepala sekolah saat menjadi guru, kadang-kadang kurang sesuai dengan kebutuahan masa kini. Keadaan demikian menunjukkan bahwa pengetahuan mereka perlu diperbaharui dan dikembangkan ke arah pertumbuhan jabatan kepala sekolah (Elsbree dan Reuter, 1964; Nurtain, 1989).

Pelatihan dapat menjadi solusi untuk memecakan problem dalam rangka mencapai produktivitas yang optimal. Menurut Johson (1976), pelatihan dimaksudnya sebagai salah satu pemenihan kebutuhan. Beberapa pemenuhan kebutuhan dimaksudkan untuk: (a) meningkatkan produktivitas, (b) meningkatkan kualitas kinerja dan mencapai semangat kerja, (c) mengembangkan keterampilan, pengetahuan, pemahaman dan sikap yang baru (d) penggunaan alat-alat, metode baru, (e) mengurangi hal-hal yang tidak efektif, misalnya ketidakhadiran atau keterlambatan, (f) mengimplementasikan kebijakan dan peraturan baru (g) memenuhi tingkat standar kompetensi, menjamin kelangsungan hidup dan pertumbuhan organisasi (Johnson, 1976). Pelatihan diharapkan dapat mengubah perilaku individu dengan memberikan tamahan pengetahuan, keterampilan atau sikap yang berfungsi sebagai upaya pengembangan profesi dan dibutuhkan untuk mencapai standar kinerja.

Menurut Mitchael (1982), hal-hal yang dapat diubah melalui pelatihan adalah: (1 ) pengetahuan, (2) skipa, (3) keterampilan, dan (4) konsep. Pengetahuan para pekerja dapat ditingkatkan melalui penyampaian informasi yang efektif, terutama yang berhubungan dengan tujuan organisasi, pengetahuan tentang prinsip-prinsip, dan pengetahuan baru. Sedangkan perubahan sikap atau "changing the attitude" meliputi sikap terhadap pekerjaan, peraturan, atasan, sesama pekerja, dan tujuan organisasi. Perubahan sikap pekerja dapat meningkatkan partisipasi kepada organisasi. Indikator sukses tidaknya pelatihan adalah dapat merubah tidaknya sikap pekerja terhadap organisasi. Disisi lain, peningkatan keterampilan melalui pelatihan merupakan sasaran pokok agar efektif dalam pelaksanaan pekerjaan. Sasaran ini lebih bersikap teknis untuk pemakaian alat, peningkatan prasarana kerja, metode kerja, dan sistem kerja baru. Sasaran pelatihan yang sulit dicapai dan bersifat menantang adalah merubah prinsip perilaku seseorang.

Dalam upaya-upaya mencapai tujuan pelatihan sebagaimana diuraikan di atas, maka dikembangkan model pelatihan bagi guru. Model pelatihan guru sekolah telah dikembangkan dalam bentuk kelompok terdiri dari 5-8 orang, yang diorganisasi untuk memperoleh kompetensi personal dan profesional. , berbagi 
pengalaman, pemecahan problem secara bersama (De Roche, 1985); Daresh dan Playko, 1989). Teknik pembinaan profesi untuk meningkatkan kemampuan guru meliputi: penataran, pertemuan pribadi, kunjungan sekolah dan petemuan dalam kelompok kerja (Pedoman Pembinan Guru, 1986).

Saat ini, banyak pelatihan yang telah dilaksanakan dalam rangka menigkatkan kemampuan profesionalisme guru. Hal yang didukung oleh adanya fakta perubahan kurikulum dari kurikulum 1994 ke kurikulum 2004 (KBK). Pelatihan yang banyak dilakukan antara lain: penyusunan silabi KBK, modelmodel pendekatan pembelajaran CTL dan pendekatan yang terkait dengan active learning. Begitu pula dengan pelatihan-pelatihan manajemen, seperti MPMBS, komite sekolah, dan pengelolaan pendidikan dengan paradigma otonomi.

\section{KESIMPULAN}

Berdasarkan uraian pada bagian terdahulu, baik pada latar belakang masalah, perumusan masalah dan pembahasan, maka pada bagian ini dapat diambil suatu simpulan bahwa untuk menjadi kepala sekolah yang handal, seseorang harus mempersiapkan dirinya untuk memiliki kemampuan manajerial, memahami iklim organisasi sert sejauh mungkin mengasah diri dengan mengikuti banyak pelatihan. Dengan demikian, sosok kepala sekolah yang memperhatikan manajemen sumber daya manusia lambat laun akan menciptakan dirinya berdaya dalam mengelola sebuah sekolah menuju harapan sebuah pihak.

\section{DAFTAR RUJUKAN}

Andrias Harefa. 2000. Menjadi Manusia Pembelajar. Jakarta:Kompas

Beach, D.S. 1980. Personnel: The Management Of People At Work. New York:Macmillan Publishing Co., Inc.

Buford Jr., James A., \& Bedeian, A.G. 1988. Management in Extention. ( $2^{\text {rd }}$ ed). Alabama:Alabama Cooperative Extentio Service, Auborn University.

Burhanuddin. 1994. Analisis Administrasi Manajemen dan Kepemimpinan Pendidikan. Jakarta: Bumi Aksara.

Davis, K \& Newstrom, J.W. 1989. Perilaku dalam Organisasi. Alih Bahasa: Agus Dharma. Jakarta: Erlangga.

De Roche, E. 1985. An Administrator's Guide for Evaluating Programs and Personnel: An Effective Schools Approach. Boston: Allyn and Bacon.

Gibson, J.L., Ivancevich, Donnelly, J.H. 1985. Organization. Terjemahan oleh Agus Dharma. 1994. Jakarta: Erlangga.

Gitusudarmo, I \& Sudita, I.N. 2000. Perilaku Keorganisasian. Yogyakarta: BPFE.

Gunawan, Imam \& Benty, Djum Djum Noor. 2017. Manajemen Pendidikan Suatu Pengantar Praktis. Bandung: Alfabeta.

Mulyasa. 2003. Manajemen Berbasis Sekolah. Bandung: PT Remaja Rosda Karya. 
Nadler, L. 1982. Designing Training Programs The Critical Events Model. Boston: addison-Wesley Publishing Company.

Notoatmodjo, S. 1992. Pengembangan Sumber Daya Manusia. Jakarta: Rineka Cipta.

Owens, R.G. 1991. Organization Behavior in Education (Fourth Edition). Boston: Allyn and Bacon, Inc.

Saberan, Riduan. 2011. Manajemen Pendidikan Berbasis Kualitas. Jember: Center for Society Studies.

Sahertian, P.A. 1976. Supervisi Pendidikan dalam Rangka Program Program In Service Education (Pengertian, Problema dan Metode). FIP IKIP Malang. 1994. Profil Pendidikan Profesional. Yogyakarta: Andi Offset.

Sudiran, Floretinus. 2011. Manajemen Mutu Terpadu Dibidang Pendidikan (Teori, Implementasi, dan Tata Langkah). Yogyakarta: Laksbang Pressindo.

Tilaar, H.A.R. 2001. Manajemen Pendidikan Nasional. Bandung: PT Remaja Rosda Karya.

Tim Pakar Manajemen Pendidikan Universitas Negeri Malang. 2002. Manajemen Pendidikan. Surabaya: Universitas Negeri Malang. 